\title{
Antiplasmodial activities of Morinda lucida (Benth) and Alstonia boonei (De wild) in mice infected with Plasmodium berghei
}

\author{
Olajide Joseph Afolabi ${ }^{*}$ and Adekemi Eunice Abejide
}

\begin{abstract}
Background: This study focused on the antiplasmodial activities of two botanicals: Morinda lucida and Alstonia boonei used in malaria treatment. The in vivo activity of the plants against established Plasmodium berghei NK65 infection was evaluated in 75 experimental mice randomly distributed into 15 groups and treated with extracts of M. lucida and A. boonei, combined recipe of the two plants at graded doses of 400,600, and $800 \mathrm{mg} / \mathrm{kg}$ and chloroquine at $10 \mathrm{mg} / \mathrm{kg}$.

Results: The results revealed that the percentage parasitemia was higher in the infected untreated mice (18.40\%) than the treated mice. Among the treated mice, the highest percentage parasitemia (6.0\%) was obtained in mice treated with $800 \mathrm{mg} / \mathrm{kg}$ of $A$. boonei while the lowest percentage parasitemia (0.0\%) was obtained in mice treated with $10 \mathrm{mg} / \mathrm{kg}$ of chloroquine. Chloroquine eliminated all the parasites (100\% clearance) when compared to the percentage clearance by the plant extracts. For the plant extracts, antiplasmodial activity was highest with the combined recipe of M. lucida and A. boonei at $800 \mathrm{mg} / \mathrm{kg}(92 \%)$ and lowest at $800 \mathrm{mg} / \mathrm{kg}$ (45\%) of M. lucida. Meanwhile, the optimal antiplasmodial activity (83\%) of M. lucida was obtained at $400 \mathrm{mg} / \mathrm{kg}$ and that of $A$. boonei was obtained at $600 \mathrm{mg} / \mathrm{kg}$ (85\%).
\end{abstract}

Conclusions: This study revealed that the two plant extracts under the study have antiplasmodial activities which are promising in reducing the morbidity and mortality of drug-resistant malaria in endemic communities.

Keywords: Alstonia boonei, Morinda lucida, Antiplasmodial activity, Parasitemia

\section{Introduction}

Malaria is an infectious disease with significant health challenges in Nigeria and other countries where the disease is endemic. Over the last 10 years, malaria prevalence has been on the increase, especially in third world countries. It was reported that over three billion people live in risk areas of the disease in 109 countries and territories around the world (Umar et al. 2012). The disease is predominant in subtropical and tropical regions such as the Americas, Asia, and Africa (Rowe 2006). Each year, there are approximately three hundred million people who suffered from the disease, the majority of

\footnotetext{
* Correspondence: ojafolabi@futa.edu.ng

Department of Biology, Federal University of Technology Akure, Akure, Nigeria
}

whom are children below 5 years domiciled in subSaharan Africa (Snow et al. 2005). The disease is a major killer disease responsible for the death of millions of children, pregnant women, and adults (Satish and Ranjana 2013). About $80 \%$ of malaria mortality is concentrated in 13 countries in Africa, and over half of the percentage mortality was recorded in Nigeria Congo, Ethiopia, Tanzania, and Kenya (World Health more seasonal (Adebayo and Krettli 2011).

Malaria is treated with chloroquine, quinine, derivatives of artemisinin, and other herbal antimalarials by suppressing the virulence of the parasites or kills them 
(Martey 2013). The well-known use of chloroquine (CQ) and antifolates (sulfadoxine-pyrimethamine) for malaria treatment is no longer effective in most endemic areas including Nigeria. The synthetic drugs are expensive with a lot of side effects, and parasites have also developed resistance to them as a result of a long-term usage abuse (Martey et al. 2013).

To overcome all these limitations on the drugs, combination therapy has currently be introduced and has shown to be the best practical solution in overcoming the resistant strains of the parasites (World Health Organization 2008b). However, clinical resistance to these drug combinations has been reported in Cambodia (Noedl et al. 2008). P. falciparum especially has been noted to develop resistance to the majority of the drugs currently used. Hence, there is an urgent need to develop alternative therapy and cheaper drugs such as herbal therapy for malaria treatment. In malariaendemic countries of the world, natural and traditional products (plant and insect products) had been employed as arsenals to combat malaria (Gupta et al. 1993). This has necessitated many countries to change their treatment policies (Wellems 2002).

Morinda lucida, "Oruwo" (local name in Yoruba tribe), has been used as a traditional remedy for the treatment of symptomatic malaria by many people in South-West part of Nigeria. Different parts of M. lucida have been reported to possess medicinal properties. The leaf extract of the plant was reported to possess trypanocidal activities (Asuzu and Chineme 1990), antimalarial activities (Makinde and Obih 1985), and aortic vasorelaxant effect (Ettarh and Emeka 2004).

M. lucida leaf extract has also been reported to have a strong oral hypoglycaemic property, and this property was attributed to increased peripheral utilization of glucose (Adeneye and Agbaje 2008). The plant contains tannins, methylanthraquinones, and heterosides. Studies have shown that $M$. lucida leave extract appears to have schizontocidal and repository effects in mice infected with Plasmodium berghei (Akanmori et al. 1994).

Alstonia boonei ('Ahun' is the local name in Yoruba tribe) is among the medicinal plants that have been widely used in recipes to treat malaria (Idowu et al. 2010). It belongs to the family Apocynaceae which consists of about 50 species widely distributed in the continents of Africa, Asia, and America. The stem bark of this plant has been found to be effective in the treatment of several diseases such as fever, painful micturition, insomnia, chronic diarrhea, and rheumatic pains (Olajide et al. 2000; Odeku et al. 2008). Olajide et al. (2000) reported that the stem bark of Alstonia boonei has antiinflammatory, antipyretic, and analgesic properties.

History has revealed that plants that are eco-friendly in nature have been considered as an important source of medicine against malaria. Botanicals and products derived from them have been used for disease treatment for centuries. Presently, it has been evaluated that $80 \%$ of the world population depends on herbal preparations to meet their health needs (Shri 2003).

The array of botanicals used in the treatment or prevention of malaria in Akure Southwest Nigeria is presented in Table 1. These medicinal plants are used in most cases, in combination with other two or more plants (such as mango, guava, or cashew leaves). The two most commonly prescribed medicinal plants $(M$. lucida and $A$. boonei) by the herbalists in the study area were used for this research. The advantages of these botanicals over the synthetic drugs have necessitated their inclusion in malaria parasites and vector control campaigns. However, additional research is required to maximize the full benefits of botanicals and respond to the health needs of people, especially in endemic countries like Nigeria (Idowu et al. 2010). Hence, this study is undertaken to examine the antimalarial activities of $M$. lucida and A. boonei plant extracts in experimentally infected mice as an animal model.

\section{Materials and methods \\ Survey of botanicals used in malaria treatment in Akure Southwest Nigeria}

The plant survey was carried out in Akure by visiting Odopetu herbal market, in Akure south L.G.A of Ondo State to find out the local names, part used, and methods of preparation of these plants.

\section{Plant collection, identification, and extraction}

Fresh leaves and barks of $M$. lucida and A. boonei were obtained, free of insecticides from Akure, Ondo State, Nigeria. The plants were authenticated by Dr. (Mrs.) B.O. Odiyi, a plant taxonomist. The leaves and barks were cleaned, air-dried at $28 \pm 20^{\circ} \mathrm{C}$, and crushed into a coarse powder using pestle and mortar. Five hundred grams in powder form of the stem and bark of each plant sample was soaked in $3 \mathrm{~L}$ of $96 \%$ ethanol for $72 \mathrm{~h}$. Also, a $500-\mathrm{g}$ combination of both plant samples (comprising $250 \mathrm{~g}$ of the individual plant powdered samples) was dissolved in 3 $\mathrm{L}$ of $96 \%$ ethanol for $72 \mathrm{~h}$. The preparations were stirred every $2 \mathrm{~h}$, thereafter decanted and filtered using a cheesecloth. The liquid filtrate obtained was filtered and concentrated using a rotary evaporator. The crude ethanolic extract was further concentrated in a vacuum oven to further remove any traces of solvent. The extract was refrigerated at $4{ }^{\circ} \mathrm{C}$ prior to use (Afolabi and Abejide 2020).

Experimental design and evaluation of in vivo activities of the plant extracts against $P$. berghei

Seventy-five mice weighing between 18 and $20 \mathrm{~g}$ were purchased from the Institute of Advanced Medical 
Table 1 Some plants used in malaria treatment in Akure Southwest Nigeria

\begin{tabular}{|c|c|c|c|c|}
\hline Botanical name & Local name (Yoruba) & Common name & Part used & Preparation \\
\hline Morinda lucida & Oruwo & Brimstone tree & Leave, bark & Decoction \\
\hline Alstonia boonie & Ahun & Stool wood & Leave, bark & Decoction \\
\hline Azadirachta indica & Dogoyaro & Neem & Leave, bark & Decoction \\
\hline Enantia chlorantia & Osopa & African yellow wood & Bark & Decoction \\
\hline Hoppocratea africana & Apoju owiwi & African paddle pod & Bark, root & Decoction \\
\hline Khaya grandifoliola & Oganwo & Mahogany & Bark & Decoction \\
\hline
\end{tabular}

Research and Training (IAMRAT), College of Medicine, University of Ibadan. The animals were acclimatized for 2 weeks at $28 \pm 2{ }^{\circ} \mathrm{C}$ with 12 -h dark/light periodicity and fed with commercial chow (purchased from Cap Feeds Ibadan, Nigeria) and water ad libitum; 2.4 inoculation of mice with P. berghei. The P. berghei (NK65) used for the in vivo study was obtained from IAMRAT.

A Swiss albino mouse (donor mouse) was intraperitoneally administered with a standard inoculum of $P$. berghei on the 1st day. On the 5th day (when the parasite had stabilized in the donor mouse) with a rising parasitemia of $20-30 \%$, the mouse was sacrificed and $0.1 \mathrm{ml}$ of acid citrate dextrose (ACD) was drawn into the syringe before blood was withdrawn from the heart of the donor mouse by cardiac puncture. The blood was diluted with isotonic saline to make inoculum for infecting experimental mice. The experimental mice were inoculated with $0.2 \mathrm{ml}$ of the diluted parasitized red blood cell (RBC) specimen (containing about $1 \times 10^{7}$ parasitized cells). The curative activity (Rane's test) of the extracts was determined in vivo according to Iyiola et al. (2011). The 75 experimental mice were divided randomly into fifteen groups of five mice each (Table 2). Subsequently,
P. berghei was injected intraperitoneally into fifty-five mice on day 1 . Seventy-two hours later, group 1-9 mice were administered through oral gavage with the extracts as described in Table 2, and groups 10 and 11 were administered with $0.2 \mathrm{ml}$ of $10 \mathrm{mg} / \mathrm{kg}$ chloroquine and 5 $\mathrm{ml} / \mathrm{kg}$ normal saline, respectively, according to the experimental design below once a day for five consecutive days. Parasitemia levels were monitored for each mouse until 7 days.

\section{Determination of parasitemia}

The blood used for thin smear preparation was obtained from the mice via a tail cut. The smears were fixed with methanol for $5 \mathrm{~min}$ and stained with 10\% Giemsa. The slides were observed under $\times 100$ objective lens of the compound microscope.

Each slide was viewed at four different fields, and the infected and total number of RBCs for each field were recorded. The data obtained were used to calculate percentage parasitemia using the method described by Hilou et al. (2006). Percentage parasitemia and percentage curative were calculated using the formulae below.

Table 2 Experimental plan for test animals and control

\begin{tabular}{|c|c|c|}
\hline Groups & Experimental plan & Remarks \\
\hline Group 1, 2, 3 & $\begin{array}{l}\text { Were infected with Plasmodium berghei and administered with Morinda lucida } \\
\text { plant extract at 400,600, and } 800 \mathrm{mg} / \mathrm{kg} \text { body weight, respectively, for } 5 \text { consecutive days }\end{array}$ & Treatment \\
\hline Group 4, 5, 6 & $\begin{array}{l}\text { Were infected with Plasmodium berghei and treated with Alstonia boonei plant } \\
\text { extract at } 400,600 \text {, and } 800 \mathrm{mg} / \mathrm{kg} \text { body weight, respectively, for } 5 \text { consecutive days }\end{array}$ & Treatment \\
\hline Group 7, 8, 9 & $\begin{array}{l}\text { Were infected with Plasmodium berghei and treated with combined recipe of Morinda } \\
\text { lucida and Alstonia boonei extract at 400,600, and } 800 \mathrm{mg} / \mathrm{kg} \text { body weight, respectively, } \\
\text { for } 5 \text { consecutive days }\end{array}$ & Combined treatment \\
\hline Groups 10 & $\begin{array}{l}\text { Were infected with Plasmodium berghei and treated with } 10 \mathrm{mg} / \mathrm{kg} \text { of chloroquine } \\
\text { phosphate solution for } 5 \text { consecutive days }\end{array}$ & Drug treatment control \\
\hline Group 11 & Were infected with Plasmodium berghei and only given $5 \mathrm{ml} / \mathrm{kg}$ of distilled water & Positive control \\
\hline Groups 12 & $\begin{array}{l}\text { Were administered with } 800 \mathrm{mg} / \mathrm{kg} \text { body weight of Morinda lucida plant extract for } 5 \\
\text { consecutive days. }\end{array}$ & Plant extract control \\
\hline Groups 13 & $\begin{array}{l}\text { Were administered with } 800 \mathrm{mg} / \mathrm{kg} \text { body weight of Alstonia boonei plant extract for } 5 \\
\text { consecutive days. }\end{array}$ & Plant extract control \\
\hline Group 14 & $\begin{array}{l}\text { Were administered with } 800 \mathrm{mg} / \mathrm{kg} \text { body weight of combined Morinda lucida and Alstonia } \\
\text { boonei extract for } 5 \text { consecutive days. }\end{array}$ & Plant extract control \\
\hline Group 15 & Were neither infected nor treated & Negative control \\
\hline
\end{tabular}




$$
\begin{aligned}
& \text { \% parasitemia }=\frac{\text { no.of parasitized RBCs }}{\text { Total RBCs }} \times 100 \\
& \begin{array}{c}
\text { curative } \\
=\frac{\text { Parasitemia before treatment-parasitemia after treatment }}{\text { Parasitemia before treatment }} \\
\quad \times 100
\end{array}
\end{aligned}
$$

\section{Data analysis}

The means of the data were computed and statistical significance was tested using one-way ANOVA. The significant means were separated using Duncan's new multiple range test (DNMRT) at $P<0.05$

\section{Results}

\section{Antiplasmodial activity of the plant extracts and chloroquine}

The antiplasmodial activity of the plant extracts at graded doses of 400,600, and $800 \mathrm{mg} / \mathrm{kg}$ body weight and the negative control group as represented in Table 3 showed that the percentage parasitemia on days 1 and 2 increased in mice treated with M. lucida at 400, 600, and $800 \mathrm{mg} / \mathrm{kg}$. Subsequently, reduction in percentage parasitemia was noted at all doses from days 3-5. However, the least percentage parasitemia (0.40) was noted in mice treated with $400 \mathrm{mg} / \mathrm{kg}$ of $M$. lucida for 5 days. In contrast, the reduction in percentage parasitemia was observed in mice treated with $A$. boonei at all doses of the extracts for 5 consecutive days. However, the comparative study of the individual plants with the combined recipes revealed that the antimalarial activity of the plants further increased as the two plants were combined at different doses. For instance, the percentage parasitemia range of the combined recipe of $M$. lucida and $A$. boonei extracts was noted to be $0.40-0.80$ while 0.40-1.40 and 0.40-1.60 were observed for M. lucida and $A$. boonei, respectively. This shows that the antimalarial activity of the plants increased when both plants were combined at graded doses of 400, 600, and 800 $\mathrm{mg} / \mathrm{kg}$. Generally, it was also noted that none of the extracts and their combined recipes could completely reduce the parasitemia to zero. Meanwhile, a complete elimination of the parasites was only noted in mice treated with chloroquine (a standard drug) at $10 \mathrm{mg} / \mathrm{kg}$ at 3 days of treatment (Table 3 ).

The results of the percentage curative as represented in Table 4 shows that chloroquine reduced the parasitemia to zero and recorded $100 \%$ percentage curative at $10 \mathrm{mg} / \mathrm{kg}$ body weight. The percentage curatives of the plant extracts and their combination vary significantly. It was also noted that the percentage curative of the combined recipe increased from 75 to $92 \%$ as the dosage increases from 400 to $800 \mathrm{mg} / \mathrm{kg}$. The percentage curative of $A$. boonei increased from 68 to $85 \%$ as the dosage increases from 400 to $600 \mathrm{mg} / \mathrm{kg}$ and subsequently decline to $75 \%$ as the dosage increased from 600 to $800 \mathrm{mg} / \mathrm{kg}$ (Table 4). In contrast, the percentage curative of $M$. lucida decreased as the dosage increases from 400 to $800 \mathrm{mg} / \mathrm{kg}$. However, the optimum antiplasmodial activity of $M$. lucida (83\%) was obtained at $400 \mathrm{mg} / \mathrm{kg}$ while that of the $A$. boonei (85\%) was noted at $600 \mathrm{mg} / \mathrm{kg}$. However, the antiplasmodial activities of the combined recipes of $M$. lucida and A. boonei performed better at each concentration than when the plant was used individually. This shows that the efficacy of the drug synergistically increased when the plants were combined.

\begin{tabular}{|c|c|c|c|c|c|}
\hline \multirow[t]{3}{*}{ Treatment groups } & \multicolumn{5}{|c|}{ Percentage parasitemia } \\
\hline & \multicolumn{5}{|l|}{ Days } \\
\hline & 1 & 2 & 3 & 4 & 5 \\
\hline M. lucida, $400 \mathrm{mg}$ & $2.40 \pm 0.24^{a}$ & $3.60 \pm 0.24^{d}$ & $3.00 \pm 0.32^{c}$ & $1.60 \pm 0.24^{b c d}$ & $0.40 \pm 0.20^{\mathrm{ab}}$ \\
\hline M. lucida, $600 \mathrm{mg}$ & $4.40 \pm 0.24^{\text {bcde }}$ & $5.40 \pm 0.24^{\mathrm{e}}$ & $2.0 \pm 0.32^{b c}$ & $1.60 \pm 0.24^{\mathrm{bcd}}$ & $1.40 \pm 0.24^{\mathrm{ab}}$ \\
\hline M. lucida, $800 \mathrm{mg}$ & $2.20 \pm 0.20^{\mathrm{a}}$ & $4.80 \pm 0.37^{e}$ & $2.60 \pm 0.40^{c}$ & $2.40 \pm 0.24^{d}$ & $1.20 \pm 0.58^{\mathrm{ab}}$ \\
\hline A. boonie, $400 \mathrm{mg}$ & $3.80 \pm 0.37^{\mathrm{abcd}}$ & $1.20 \pm 0.20^{\mathrm{a}}$ & $1.20 \pm 0.20^{a b}$ & $1.00 \pm 0.00^{\mathrm{abc}}$ & $1.00 \pm 0.32^{\mathrm{ab}}$ \\
\hline A. boonie, $600 \mathrm{mg}$ & $2.80 \pm 1.07^{\mathrm{ab}}$ & $1.60 \pm 0.40^{\mathrm{ab}}$ & $1.20 \pm 0.37^{\mathrm{ab}}$ & $0.60 \pm 0.24^{\mathrm{ab}}$ & $0.40 \pm 0.24^{\mathrm{ab}}$ \\
\hline A. boonie, $800 \mathrm{mg}$ & $6.00 \pm 0.32^{\mathrm{e}}$ & $3.20 \pm 0.20^{c d}$ & $2.20 \pm 0.20^{b c}$ & $2.00 \pm 0.32^{c d}$ & $1.60 \pm 0.40^{\mathrm{ab}}$ \\
\hline Combined recipe, 400 mg & $3.20 \pm 0.37^{\mathrm{abc}}$ & $0.80 \pm 0.20^{\mathrm{a}}$ & $1.0 \pm 0.32^{\mathrm{ab}}$ & $0.60 \pm 0.24^{\mathrm{ab}}$ & $0.80 \pm 0.37^{\mathrm{ab}}$ \\
\hline Combined recipe, 600 mg & $3.80 \pm 0.97^{\mathrm{abcd}}$ & $2.20 \pm 0.58^{b c}$ & $2.20 \pm 0.80^{b c}$ & $1.60 \pm 0.60^{\mathrm{bcd}}$ & $0.40 \pm 0.24^{\mathrm{ab}}$ \\
\hline Combined recipe, 800 mg & $5.80 \pm 0.49^{e}$ & $2.60 \pm 0.24^{b c d}$ & $0.60 \pm 0.24^{\mathrm{a}}$ & $0.60 \pm 0.24^{\mathrm{ab}}$ & $0.40 \pm 0.24^{\mathrm{ab}}$ \\
\hline Chloroquine, 10 mg/kg & $5.40 \pm 0.24^{\mathrm{de}}$ & $2.60 \pm 0.24^{\mathrm{bcd}}$ & $0.00 \pm 0.00^{\mathrm{a}}$ & $0.00 \pm 0.00^{\mathrm{a}}$ & $0.00 \pm 0.00^{\mathrm{a}}$ \\
\hline Infected Untreated & $4.80 \pm 0.37^{\text {cde }}$ & $7.00 \pm 0.44^{f}$ & $11.40 \pm 0.60^{d}$ & $13.60 \pm 0.87^{e}$ & $18.40 \pm 0.98^{\mathrm{b}}$ \\
\hline
\end{tabular}

Table 3 Curative effect of Morinda lucida and Alstonia boonei plant extracts and chloroquine against P. berghei infection in mice for five consecutive days 
Table 4 Comparative antiplasmodial activity of Morinda lucida, Alstonia boonei, the combined recipe of plant extracts and chloroquine (a standard drug) to $10 \mathrm{mg} / \mathrm{kg}$ against $P$. berghei

\begin{tabular}{lllll}
\hline Plant extracts (mg/kg) & Parasitemia & & $\begin{array}{l}\text { Percentage } \\
\text { curative (\%) }\end{array}$ \\
\cline { 3 - 4 } Morinda lucida & 400 & $2.40 \pm 0.24^{\mathrm{a}}$ & $0.40 \pm 0.20^{\mathrm{ab}}$ & 83 \\
& 600 & $4.40 \pm 0.24^{\mathrm{bcde}}$ & $1.40 \pm 0.24^{\mathrm{ab}}$ & 68 \\
& 800 & $2.20 \pm 0.20^{\mathrm{a}}$ & $1.20 \pm 0.58^{\mathrm{ab}}$ & 45 \\
Alstonia boonei & 400 & $3.80 \pm 0.37^{\mathrm{abcd}}$ & $1.00 \pm 0.32^{\mathrm{ab}}$ & 68 \\
& 600 & $2.80 \pm 1.07^{\mathrm{ab}}$ & $0.40 \pm 0.24^{\mathrm{ab}}$ & 85 \\
& 800 & $6.00 \pm 0.32^{\mathrm{e}}$ & $1.60 \pm 0.40^{\mathrm{ab}}$ & 73 \\
Combined recipe & 400 & $3.20 \pm 0.37^{\mathrm{abc}}$ & $0.80 \pm 0.37^{\mathrm{ab}}$ & 75 \\
& 600 & $3.80 \pm 0.97^{\mathrm{abcd}}$ & $0.40 \pm 0.24^{\mathrm{ab}}$ & 89 \\
& 800 & $5.80 \pm 0.49^{\mathrm{e}}$ & $0.40 \pm 0.24^{\mathrm{ab}}$ & 92 \\
Chloroquine & 10 & $5.40 \pm 0.24^{\mathrm{de}}$ & $0.00 \pm 0.00^{\mathrm{a}}$ & 100 \\
\hline
\end{tabular}

\section{Discussion}

Malaria is a fatal parasitic infection especially in the tropical African and Asian continents, and it is believed that it kills more than AIDS and the most vulnerable are children below 5 years (WHO 2014). Herbal remedy, which in most cases, is a combination of two or more plants is usually taken ad libitum for malaria treatment or prevention in Africa (Oludele and Olufunso 2018). The curative antiplasmodial tests indicated that the mice treated with $M$. lucida, A. boonei, and their combined recipes at graded doses of 400,600, and $800 \mathrm{mg} / \mathrm{kg}$ body weight resulted in reduced parasite load as compared to the untreated mice. The comparative curative antiplasmodial activity of $M$. lucida and $A$ boonei, the combined recipe and chloroquine at $10 \mathrm{mg} / \mathrm{kg}$ body weight from this study shows that chloroquine, the standard drug, cleared the parasites by $100 \%$ compared to the percentage of clearance by plant extracts which varies at graded doses of 400, 600, and $800 \mathrm{mg} / \mathrm{kg}$ against $P$. berghei infection in mice on the fifth day of treatment. For the plant extracts, antiplasmodial activity was highest with the combined recipe of the extracts at $800 \mathrm{mg} / \mathrm{kg}$ and $600 \mathrm{mg} / \mathrm{kg}, 600 \mathrm{mg} / \mathrm{kg}$ of $A$. boonei, and $400 \mathrm{mg} / \mathrm{kg}$ of $M$. lucida plant extracts compared to other graded doses of M. lucida at $600 \mathrm{mg} / \mathrm{kg}$, A. boonei at $800 \mathrm{mg} / \mathrm{kg}$, and the combined recipe of the two extracts at $400 \mathrm{mg} / \mathrm{kg}$. Parts of $A$. boonei plant are employed in the treatment of a variety of ailments in Africa, and the stem bark has been used as useful plant agent for the treatment of malaria, intestinal helminths, muscular pain, insomnia, hypertension, fever, painful micturition, chronic diarrhea, and rheumatic pains, as anti-venom for snake bites and in the treatment of arrow poisoning (Faparusi and Bassir 1972; Oliver-Bever 1986; Kweifo-Okai et al. 1995). In addition, the antimalarial property of the stem bark of $A$. boonei elucidated in this research concurred with the work of other authors (Bello et al. 2009; Iyiola et al. 2011). The authors in their separate studies reported the antimalarial activities of different fractions of the stem bark extract of A. boonei. Also, Odugbemi and Akinsulire (2007) and Gbadamosi et al. (2011) confirmed the indigenous use of $A$. boonei for malaria treatment in southwestern Nigeria.

In West Africa, M. lucida is an important plant in traditional medicine. In Nigeria, $M$. lucida has also been noted as one of the four most important plants in the preparation of traditional medicines against fever (Lawal et al. 2011). Obih et al. (1985) reported in vitro activity of $M$. lucida leaf extract against $P$. falciparum and activity of $M$. lucida against $P$. berghei in mice. Awe and Makinde (1998) also been reported that the stem bark of $M$. lucida inhibited the maturation of a drug-sensitive strain of P. falciparum in rabbit in vivo technique

The in vivo curative antiplasmodial test results of this study indicated that the mice treated with M. lucida, A. boonei, and combined recipes of the plant extracts at graded doses of 400, 600, and $800 \mathrm{mg} / \mathrm{kg}$ showed no significant difference $(P<0.05)$ against $P$. berghei infected mice on the day 5 of the treatment. Chloroquine reduced the parasites by $100 \%$ at $10 \mathrm{mg} / \mathrm{kg}$ body weight compared to the plant extracts with varying levels of percentage curative.

\section{Conclusions}

The study indicates that the combined recipe of $M$. lucida and $A$. boonei plant extracts at $800 \mathrm{mg} / \mathrm{kg}$ and $600 \mathrm{mg} / \mathrm{kg}$ has a synergistic effect on the parasite and hence produced more curative effects than when the plants were used individually. However, M. lucida when recommended at $400 \mathrm{mg} / \mathrm{kg}$ of body weight produced optimal curative effect than when used at higher doses. In contrast, $A$. boonei produces optimal antimalarial activity when recommended at $600 \mathrm{mg} / \mathrm{kg}$ of body weight. Therefore, medicinal plants should be considered veritable alternatives in malaria control and prevention.

\section{Abbreviations \\ A. boonei: Alstonia boonei; ACD: Acid citrate dextrose; ACTs: Artemisinin combination therapies; CQ: Chloroquine; DNMRT: Duncan's new multiple range test; IAMRAT: Institute of Advanced Medical Research and Training; LGA: Local government area; M. lucida: Morinda lucida; RBCs: Red blood cells; UCH: University College Hospital; WHO: World Health Organization \\ Acknowledgements \\ The authors acknowledged the contribution of Mrs. V.A. Thomas of IAMRAT for her professional assistance during the in vivo experiment. The authors are also grateful to Mrs. E.T. Ojo, the chief technologist of the Department of Biology, Federal University of Technology Akure, Nigeria, for her technical assistance during the laboratory work.}

\section{Authors' contributions}

OJA and EAA involved in the study design. OJA and EAA involved in the field and the laboratory works. Data analysis was undertaken by the authors OJA and EAA. OJA and EAA were the major contributors in writing the manuscript. The authors read and approved the final manuscript. 


\section{Funding}

No funding was obtained for this study.

\section{Availability of data and materials}

All data generated or analyzed during this study are included in this published article [and its supplementary information files].

\section{Ethics approval and consent to participate}

The ethics and consent concerning the use of mice for this research were approved by the Institute of Advanced Medical Research and Training, University College Hospital Ibadan.

\section{Consent for publication}

The authors give their consent to the Bulletin of the National Research

Centre to publish this manuscript if accepted for publication.

\section{Competing interests}

The authors declare that they have no competing interests.

Received: 19 March 2020 Accepted: 20 May 2020

Published online: 01 June 2020

\section{References}

Adebayo JO, Krettli AU (2011) Potential antimalarials from Nigerian plants: a review. J Ethnopharmacol 133(2):289-302

Adeneye AA, Agbaje EO (2008) Pharmacological evaluation of ora hypoglycaemic and antidiabetic effects of fresh leaves ethanol extract of Morinda lucida Benth in normal and alloxan induced diabetic rats. Afr J Biomed Res 11(1):65-71

Afolabi OJ, Abejide EA (2020) Hematological and biochemical effects of Morinda lucida and Alstonia boonei on the liver and kidney of mice infected with Plasmodium berghei. Adv Traditional Med https://doi.org/10.1007/s13596 020-00436-8

Akanmori BD, Waki S, Suzuki M (1994) Immunology G2a isotype may have a protective role in Plasmodium berghei NK65 infection in immunized mice. Parasitol Res 80:638-641

Asuzu IU, Chineme CN (1990) Effects of Morinda lucida leaf extract on Trypanosoma brucei brucei infection in mice. J Ethnopharmacol 30:307-331

Awe SO, Makinde JM (1998) Evaluation of sensitivity of Plasmodium falciparum to Morinda lucida leaf extract sample using rabbit in vitro microtest technique. Indian J Pharm 30:51-53

Bello IS, Oduola T, Adeosun OG, Omisore NOA, Raheem GO, Ademosun AA (2009) Evaluation of antimalarial activity of various fractions of Morinda lucida and Alstonia boonei stem bark. Global J Pharmacol 3(3):163-165

Ettarh RR, Emeka P (2004) Morinda lucida extract induces endotheliumindependent relaxation of rat aorta. Fitoterapia 75(3-4):332-336

Faparusi SI, Bassir O (1972) Triterpines from Alstonia boonei. Phytochemistry 21: 3083-3084

Gbadamosi IT, Moody JO, Lawal AM (2011) Phytochemical screening and proximate analysis of eight ethnobotanicals used as antimalaria remedies in Ibadan. Nigerian J Appl Bioscience 44:2967-2971

Gupta MP, Correa MD, Solís PN, Jones A, Galdames C, Guionneau-Sinclair F (1993) Medicinal plant inventory of Kuna Indians: part 1. J Ethnopharmacol 40:77109

Hilou H, Nacoulma OG, Guiguemde TR (2006) In vitro antimalarial activity of extracts of Amaranthus spinosus L. and Boerhavia erecta L. in mice. J Ethnopharmacol 103:235-240

Idowu OA, Soniran OT, Ajana O, Aworinde DO (2010) Ethnobotanical survey of antimalarial plants used in Ogun State, Southwest, Nigeria. Afr J Pharmacol 4 055-060

lyiola OA, Tijani AY, Lateef KM (2011) Antimalarial activity of ethanolic stem bark extract of Alstonia boonei in mice. Asian J Biol Sci 4.235-243

Kweifo-Okai G, Bird D, Field B, Ambrose R, Carroll AR, Smith P, Valdes R (1995) Anti-inflammatory activity of a Ghanaian herbal preparation III. J Ethnopharmacol 46:7-15

Lawal HO, Etatuvie SO, Fawehinmi AB (2011) Ethnomedicinal and pharmacological properties of Morinda lucida. J Nat Prod 5:93-99

Makinde JM, Obih PO (1985) Screening of Morinda lucida leaf extract for antimalaria action on Plasmodium berghei in mice. Afr J Med Sci 14:59-63
Martey ONK, Shittah-Bay O, Owusu J, Okine LKN (2013) The antiplasmodial activity of an herbal antimalarial, AM 207 in Plasmodium berghei-infected Balb/c Mice: absence of organ specific toxicity. J Med Sci 13:537-545

Noedl HY, Schaecher K, Smith BL, Socheat D, Fukuda MM (2008) Evidence of artemisinin-resistant malaria in western Cambodia. N Engl J Med 359:2619_ 2620

Obih PO, Makinde JM, Laoye JO (1985) Investigations of various extracts of Morinda lucida for antimalaraial actions on Plasmodium berghei berghei in mice. Afr J Med Sci 14:45-49

Odeku OA, Adegoke OA, Majekodunmi SO (2008) Formulation of the extract of the stem bark of Alstonia boonei as tablet dosage form. Trop J Pharm Res 7 987-994

Odugbemi TO, Akinsulire OR (2007) Medicinal plants useful for malaria therapy in Okeigbo, Ondo State, Southwest, Nigeria. Afr J Tradit Complement Altern Med 4(2):191-198

Olajide OA, Awe SO, Makinde JM, Ekhelar Al, Olusola A, Morebise O, Okpako DT (2000) Studies on the anti-inflammatory, antipyretic analgesic properties of Alstonia boonei stem bark. J Ethnopharmacol 71(1-2):179-186

Oliver-Bever B (1986) Medicinal plant in tropical West Africa. Cambridge University Press:89-90

Oludele JO, Olufunso OO (2018) Toxicology of solvent extract and fractions of Alstonia boonei (DC.) wild stem bark in rats. Laboratories for Biomembrane Research and Biotechnology, Department of Biochemistry, Faculty of Basic Medical Sciences, College of Medicine, University of Ibadan. J Herbmed Pharmacol 7(3):129-135

Rowe AK (2006) The burden of malaria mortality among African children in the year 2000. Int J Epidemiol 35:691-704

Satish B, Ranjana K (2013) Herbal plants used for the treatment of malaria- a literature review. Department of Pharmacology, Mahatma Gandhi Institute of Medical Sciences, Sewagram, Wardha, Maharashtra 442102, Indian. J Pharmacog Phytochem 1:6

Shri JNM (2003) Ginger: it's role in xenobiotic metabolism. Indian Council Med Res Bull 33(6):57-63

Snow RW, Guerra CA, Myint HY, Hay SI (2005) The global distribution of clinical episodes of Plasmodium falciparum malaria. Nature 434(7030):214-217

Umar MB, Ogbadoyi EO, Ilumi JY, Kabiru AY, Maina HI, Ibikunle GM (2012) In-vivo antiplasmodial efficacy of fractions of crude methanolic root extract of Morinda lucida. Int J Drug Res Technol 2(7):486-491

Wellems TE (2002) Plasmodium chloroquine resistance and the search for a replacement antimalarial drug. Science 298(5591):124-126

World Health Organization. Guinea-Bissau. 2008a Available from: https://who.int/ malaria/publications/country-profiles/profile_gnb_en.pdf.

World Health Organization (2008b) World Malaria Report. World Health Organization, Geneva, pp 7-15 99101

World Health Organization (2014) World Malaria Report. WHO Press, Geneva

\section{Publisher's Note}

Springer Nature remains neutral with regard to jurisdictional claims in published maps and institutional affiliations.

\section{Submit your manuscript to a SpringerOpen ${ }^{\circ}$ journal and benefit from:}

- Convenient online submission

- Rigorous peer review

- Open access: articles freely available online

High visibility within the field

- Retaining the copyright to your article

Submit your next manuscript at $>$ springeropen.com 